\title{
Larval stages of crustacean species of interest for conservation and fishing exploitation in the western Mediterranean
}

\author{
ASVIN P. TORRES ${ }^{1}$, ANTONINA DOS SANTOS ${ }^{2}$, FRANCISCO ALEMANY $^{1}$ \\ and ENRIC MASSUTÍ ${ }^{1}$ \\ ${ }^{1}$ Instituto Español de Oceanografía, Centre Oceanogràfic de les Balears, Moll de Ponent s/n, 07015 Palma de Mallorca, \\ Spain. E-mail: asvin.perez@ba.ieo.es \\ ${ }^{2}$ Instituto Português do Mar e da Atmosfera (IPMA), Avenida de Brasília s/n, 1449-006 Lisbon, Portugal.
}

\begin{abstract}
SUMMARY: Decapod crustaceans are the main target species of deep water bottom trawl fisheries in the western Mediterranean. Despite their importance for fisheries and conservation, little is known about their larval development, especially in the case of deep water species. In this paper we present new information on the occurrence and morphology of larval stages for some species of commercial interest based on samples collected off the Balearic Islands. Mesozooplankton sampling was carried out using depth-stratified sampling devices at two stations located on the continental shelf break and middle slope, in the northwest and south of Mallorca in late autumn 2009 and summer 2010. We describe in detail the second mysis stage of the red shrimp Aristeus antennatus, not previously known, and the first larval stage of the slipper lobster Scyllarides latus, poorly described almost a hundred years ago. We also report the second finding of larvae of the spider crab Maja squinado and the first capture from the field of larval stages of the rose shrimp Parapenaeus longirostris and slipper lobster in the Mediterranean.
\end{abstract}

Keywords: Aristeus antennatus, Parapenaeus longirostris, Scyllarides latus, Maja squinado, larval stages, Decapoda, western Mediterranean.

RESUMEN: ESTADOS LARVARIOS DE CRUSTÁCEOS DE ESPECIAL INTERÉS PARA SU CONSERVACIÓN Y EXPLOTACIÓN PESQUERA EN EL MEDITERRRÁNEO OCCIDENTAL. - Los crustáceos decápodos son especies objetivo de la pesquería de arrastre de fondo y de algunas modalidades de pesca artesanal en el Mediterráneo Occidental. A pesar de su importancia económica y la preocupación por la conservación de algunas de estas especies, la mayoría de sus estados de desarrollo larvario son desconocidos. En este trabajo se aporta nueva información sobre la presencia y la morfología de algunos estados larvarios de estas especies, a partir de muestras recolectadas alrededor de las Islas Baleares. El muestreo fue estratificado por profundidad y se realizó en dos estaciones del margen de la plataforma continental y el talud medio, situadas al norte y sur de Mallorca, durante finales de otoño de 2009 y verano de 2010. Se describe en detalle la morfología de la segunda misis de gamba roja (Aristeus antennatus), desconocida hasta la fecha, y el primer estado de desarrollo de la cigarra de mar (Scyllarides latus), descrito de manera sucinta hace casi un siglo. También se aporta información sobre el segundo hallazgo mundial de estadios larvarios de centolla (Maja squinado) y la primera vez que se capturan larvas de gamba blanca (Parapenaeus longirostris) y cigarra de mar en el medio natural del Mediterráneo.

Palabras clave: Aristeus antennatus, Parapenaeus longirostris, Scyllarides latus, Maja squinado, estados larvarios, decápodos, Mediterráneo occidental.

\section{INTRODUCTION}

Decapod crustaceans such as Nephrops norvegicus and some Dendrobranchiata shrimps (Aristeus antennatus, Aristeomorpha foliacea and Parapenaeus longirostris) are the main target species of the deep water bottom trawl fishery carried out in the western Mediterranean (Sardà 1998, Sardà et al. 2004; Mo- 
ranta et al. 2008). Other decapod crustaceans, such as lobsters, spiny and slipper lobsters, and spider crabs, are also species of interest for the small-scale fisheries (Goñi and Latrouite 2005), although during the last few decades some of these taxa have almost disappeared in catches (Bannister 1993, Spanier and Lavalli 1998).

It is currently accepted that, for the management of sustainable crustacean fisheries, information on the biology of the species, their larval ecology and recruitment characteristics should be integrated (Fehlauer and Freire 2002). While long-term information is usually available on the fisheries and adult populations for most commercially important species, larval records are much scarcer or even completely lacking. The study of planktonic stages and the larval transport modeling of deep-sea benthic invertebrates is one of the most efficient and economical ways to acquire this kind of information, especially because studies on adult benthic populations require a greater investment (Yearsley and Sigwart 2011). However, with larval development known for only a small number of species (Harvey et al. 2002), there is a need for more research on these developmental stages.

In the western Mediterranean, some studies have provided larval morphological descriptions for continental shelf species (e.g. Guerao and Abelló 1997, 1999; Guerao et al. 2006) and information on decapod larva communities (e.g. Fusté 1982, 1987, Olivar et al. 1998, González-Gordillo and Rodríguez 2003), whereas others have presented data on their vertical distribution and the meso-scale horizontal patterns of larval distribution in the neuston layer (e.g. Abelló and Guerao 1999). However, we still have poor knowledge concerning the morphology of larval stages of most continental slope species. This is largely due to the relative scarcity of these species in standard plankton samples and the lack of expertise for their correct identification and recognition in the samples. Most of all, difficulties in the capture of adult specimens alive and their reproduction and survival under laboratory conditions have prevented the description of the complete larval series for Aristeus antennatus and Scyllarides latus leading to a point when any information on their morphology and distribution is valuable to better understand their ecological traits.

In the western Mediterranean, the shrimps P. longirostris (Lucas 1846) and A. antennatus (Risso 1816) are exploited by bottom trawlers on the upper and middle continental slope bottoms, respectively. They are well known in terms of their biology and fishery (e.g. Sardà et al. 2004, Cartes et al. 2008, Guijarro et al. 2008, 2009, Moranta et al. 2008 and references therein). However, their larvae have been proving difficult to find and only a few references on their occurrence and morphology are available to date (Heldt 1938, 1954, 1955, Seridji 1971, Dos Santos 1998, Carbonell et al. 2010, Landeira 2010). Scyllarides latus (Latreille, 1803) and Maja squinado (Herbst, 1788) represent smaller-scale fisheries resources that are currently included in the list of species whose exploitation is regulated under Annex III of the Barcelona Convention Protocol (1976). While the slipper lobster $S$. latus has been fished intensively, only some larval stages have been captured and described (stage I by Santucci 1925, 1928; stage VIII by Maigret 1978; stage XI by Martins 1985). The crab M. squinado, whose larval stages were described by Bourdillon-Casanova (1960) and Guerao et al. (2008), was considered commercially extinct. As a consequence, the regional government of the Balearic Islands has been developing a programme for restocking in the archipelago since 2006 (http://dgpesca.caib.es).

The aim of the present study is to provide new information on the occurrence and morphology of larval stages of the red shrimp Aristeus antennatus, the rose shrimp Parapenaeus longirostris, the slipper lobster Scyllarides latus and the Mediterranean spider crab Maja squinado, all species that are important for fisheries management and conservation purposes.

\section{MATERIALS AND METHODS}

Two multidisciplinary research surveys were conducted off the Balearic Archipelago (western Mediterranean; Fig. 1) during late autumn (29 November to 18 December 2009) and summer (11 to 30 July 2010). The main objectives of the surveys were to determine the taxonomic composition, abundance, structure and vertical distribution of the meroplanktonic community at two stations located over $200 \mathrm{~m}$ and $900 \mathrm{~m}$ depth (shelf break and middle slope, respectively), off the northwest and south of Mallorca Island (Balearic and Algerian sub-basin, respectively), each site representing different environmental conditions (Pinot et al. 2002, López-Jurado et al. 2008).

To determine vertical distribution of decapods larvae during the daily cycle, series of oblique hauls were performed at four stations for $36 \mathrm{~h}$ at each site. During the course of the study a total of 218 depth-stratified mesozooplankton samples were selected to study decapod larvae, which were integrated in 34 hauls. From these, 18 were collected using HYDRO-BIOS multi-net in 2009 and 16 with a multiple opening closing net and environmental sensing system (MOCNESS) in 2010 (Olivar et al. 2012). During each oblique haul along the whole column, generally performed down to $200 \mathrm{~m}$ depth on the shelf break and $500 \mathrm{~m}$ (in summer) or 850 $\mathrm{m}$ (in late autumn) on the middle slope, seven and five depth strata were fished in summer and late autumn, respectively. The thicknesses of these strata depended on bathymetry and season. In late autumn the strata were 200-120, 120-90, 90-60, 60-30 and $30 \mathrm{~m}$ from the surface on the shelf and 850-600, 600-350, 350$200,200-60$ and $60 \mathrm{~m}$ from the surface on the slope. In summer the strata were 200-150, 150-125, 125-100, $100-75,75-50,50-25$ and $25 \mathrm{~m}$ from the surface on the shelf and 500-400, 400-200, 200-125, 125-75, 75-50, $50-25$ and $25 \mathrm{~m}$ from the surface on the slope. The net mouth openings were 0.25 and $1 \mathrm{~m}^{2}$, respectively, and 


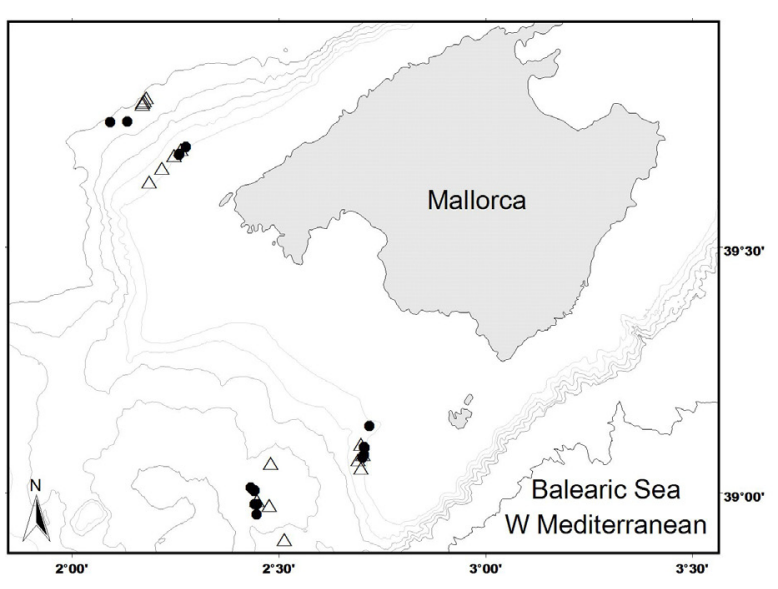

Fig. 1. - Study area and plankton stations located over shelf break and middle slope (dots: late autumn 2009; triangles: summer 2010).

mesh size was $333 \mu \mathrm{m}$ for both net types. Both devices were towed at $\sim 2$ knots. Immediately after collection, all samples were preserved in $\sim 4 \%$ borax-buffered formaldehyde prepared using seawater. In the laboratory, samples were subsequently sorted for decapod crustacean larvae and identified to species and developmental stage, whenever possible, using identification keys (Dos Santos and Lindley 2001, Dos Santos and González-Gordillo 2004) and the following available descriptions for species: Heldt (1955) for Aristeus antennatus, Heldt (1938) for Parapenaeus longirostris, Guerao et al. (2008) for Maja squinado and Santucci (1928) for Scyllarides latus.

Drawings and measurements were made with a camera lucida on a binocular Leica M205C stereo microscope. Setal observations and their drawings were made using a Zeiss compound microscope with a camera lucida. The preparation of slides was temporary. Larval description followed the standards described by Clark et al. (1998) and the setal terminology used was that established by Ingle (1993) and Garm (2004). Whenever necessary, the long plumose setae on distal exopod segments were drawn truncated and setulation on appendages is absent. Setal counts are presented in a proximal to distal sequence. The following measurements were taken: total length (TL), between the tip of the rostrum and the posterior end of the telson; rostrodorsal length of brachyuran zoea (RDL), between the tips of the dorsal and rostral spines; and carapace length $(\mathrm{CL})$, from the tip of the rostrum to the posterior margin of the carapace. For Scyllarides latus and Maja squinado, carapace maximum width $(\mathrm{CW})$ was also measured.

All studied specimens are deposited at the Centre Oceanogràfic de les Balears, with the following catalogue numbers: for $P$. longirostris one second protozoea from late autumn, ID2_1209_C1.2.N4 and one from summer, ID2_0710_E11N7; for A. antennatus one second protozoea, ID2_0710_E6N7, another second protozoea, ID2_0710_E24N8, and a second mysis dissected, ID2_0710_E18N8; for S. latus a first zoea dissected, ID2_0710_E19N8; and for M. squinado a second zoea, ID2_0710_E18N8.

\section{RESULTS}

\section{Occurrence and abundance of larval stages}

A total of 7448 decapod larvae belonging to 120 different taxa were identified to the lowest recognizable taxonomic level. Among these, we identified and measured a total of seven specimens of species that are of high interest for conservation and fishing exploitation in the western Mediterranean. Three larvae of $A$. antennatus were captured in summer, of which two corresponded to the second protozoea (PII) and one to the second mysis stage (MII). Two specimens of the second protozoea (PII) larval stage of $P$. longirostris were also found in the samples in both seasons. Also, the first larval stage (ZI) of S. latus and the second zoea (ZII) of M. squinado were captured in summer. Relevant information about these specimens and the hauls in which they were found, such as size, density, date, geographic point, time of day, water depth stratum and bottom depth, is shown in Table 1.

\section{Morphological description of mysis II of Aristeus antennatus (Figs 2 and 3)}

Size: $4.1 \mathrm{~mm}$ TL and $1.6 \mathrm{~mm}$ CL.

Pereion (Fig. 2A): with gastro-frontal and gastroorbital carinas, rostrum slender and slightly upwardpointing, extending to end of second segment of antennular peduncle, with 4 very small simple setae (Fig.

TABLE 1. - Information on number (N), total length (TL), TL zoea of Brachyura (RDL), carapace length (CL), carapace maximum width (CW), densities, date, geographical location, time of day, captured depth stratum and bottom depth for captured larvae of Aristeus antennatus, Parapenaeus longirostris, Scyllarides latus and Maja squinado. Development stages: PII, second protozoea stage; ZI, first zoeal stage; ZII, second zoeal stage; MII, second mysid stage.

\begin{tabular}{|c|c|c|c|c|c|c|c|c|c|c|}
\hline Species and stage & $\mathrm{N}$ & $\begin{array}{c}\mathrm{LT} \\
(\mathrm{mm})\end{array}$ & $\begin{array}{l}\mathrm{CL}, \mathrm{CW} \\
(\mathrm{mm})\end{array}$ & $\begin{array}{c}\text { Density } \\
\left(\mathrm{N} / 1000 \mathrm{~m}^{3}\right)\end{array}$ & Date & $\begin{array}{l}\text { Latitude } \\
\text { (N) }\end{array}$ & $\begin{array}{l}\text { Longitude } \\
\text { (E) }\end{array}$ & $\begin{array}{l}\text { Time } \\
\text { (GMT) }\end{array}$ & $\begin{array}{l}\text { Captured } \\
\text { strata }(\mathrm{m})\end{array}$ & $\begin{array}{c}\text { Bottom } \\
\text { depth }(m)\end{array}$ \\
\hline A. antennatus MII & 1 & $4.06 \mathrm{LT}$ & $1.65 \mathrm{CL}$ & 9.3 & 24/07/2010 & $39^{\circ} 51.00^{\prime}$ & $2^{\circ} 14.40^{\prime}$ & $10: 30$ & $0-25$ & 979 \\
\hline \multirow[t]{2}{*}{ A. antennatus PII } & 1 & $1.59 \mathrm{LT}$ & $0.73 \mathrm{CL}$ & 4.4 & $26 / 07 / 2010$ & $39^{\circ} 40.98^{\prime}$ & $2^{\circ} 12.30^{\prime}$ & $8: 33$ & $0-25$ & 222 \\
\hline & 1 & $1.63 \mathrm{LT}$ & $0.83 \mathrm{CL}$ & 3.9 & $15 / 07 / 2010$ & $39^{\circ} 00.96$ & $2^{\circ} 24.72$ & $12: 30$ & $25-50$ & 900 \\
\hline \multirow[t]{2}{*}{ P. longirostris PII } & 1 & $2.35 \mathrm{LT}$ & $0.90 \mathrm{CL}$ & 17.8 & $17 / 07 / 2010$ & $39^{\circ} 01.92^{\prime}$ & $2^{\circ} 41.70^{\prime}$ & $13: 29$ & $25-50$ & 248 \\
\hline & 1 & $2.86 \mathrm{LT}$ & $1.32 \mathrm{CL}$ & 11.1 & $02 / 12 / 2009$ & $39^{\circ} 05.52^{\prime}$ & $2^{\circ} 42.42$ & $13: 30$ & $30-60$ & 234 \\
\hline S. latus ZI & 1 & $1.95 \mathrm{LT}$ & $1.15 \mathrm{CL} 1.06 \mathrm{CW}$ & 7.1 & $24 / 07 / 2010$ & $39^{\circ} 49.08^{\prime}$ & $2^{\circ} 09.06^{\prime}$ & $0: 10$ & $0-25$ & 974 \\
\hline M. squinado ZII & 1 & $0.36 \mathrm{RDL}$ & $1.32 \mathrm{CL} 1.12 \mathrm{CW}$ & 9.3 & $24 / 07 / 2010$ & $39^{\circ} 51.00^{\prime}$ & $2^{\circ} 14.40^{\prime}$ & $10: 30$ & $0-25$ & 979 \\
\hline
\end{tabular}




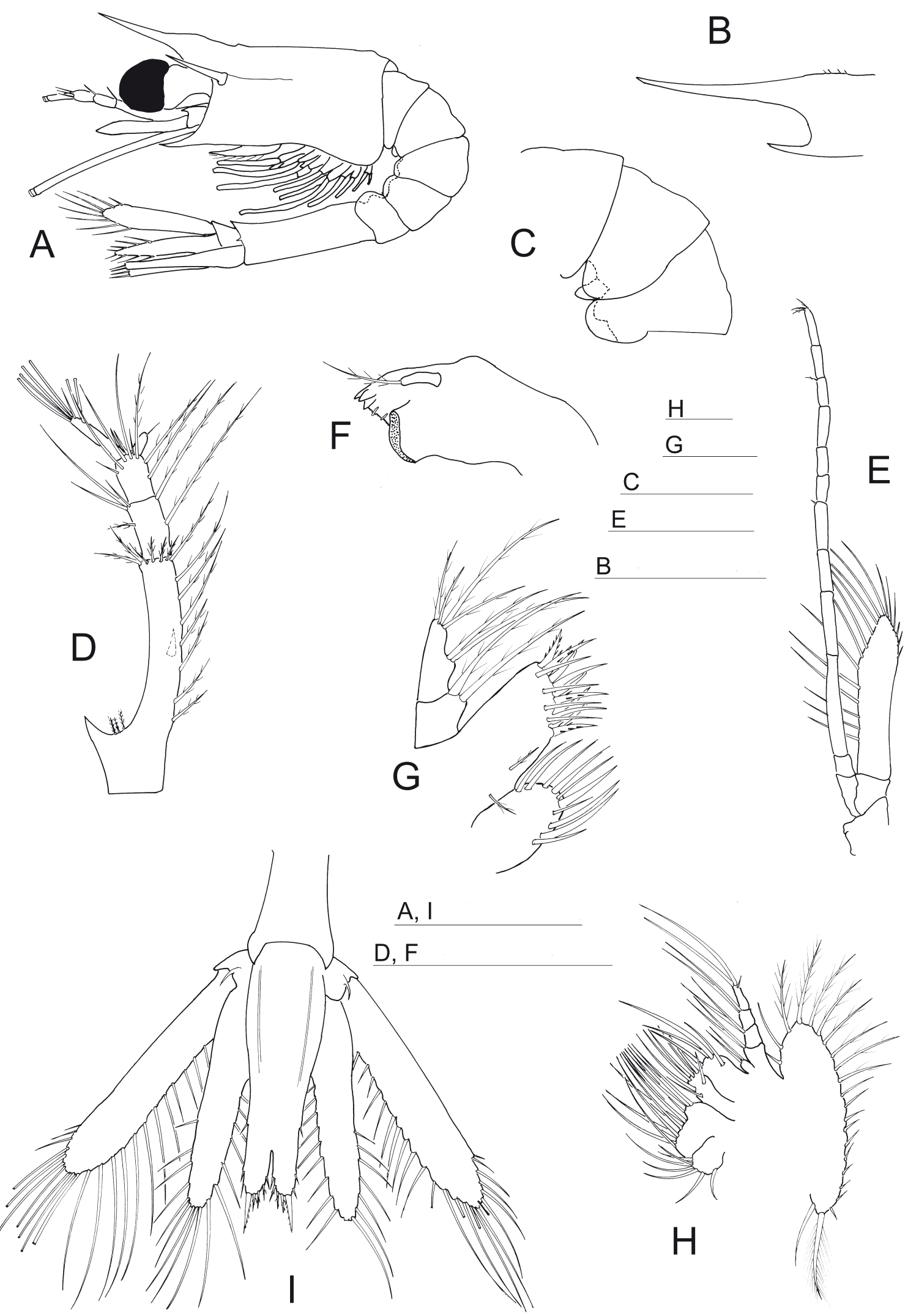

FIG. 2. - Mysis II of the red shrimp Aristeus antennatus (Risso, 1816). A, lateral view; B, rostrum; C, detail of pleon and pleopods of somites 1-3; D, antennule; E, antenna; F, right mandible; G, maxillule; H, maxilla; I, uropods and telson. Scale bar: 1 mm. 

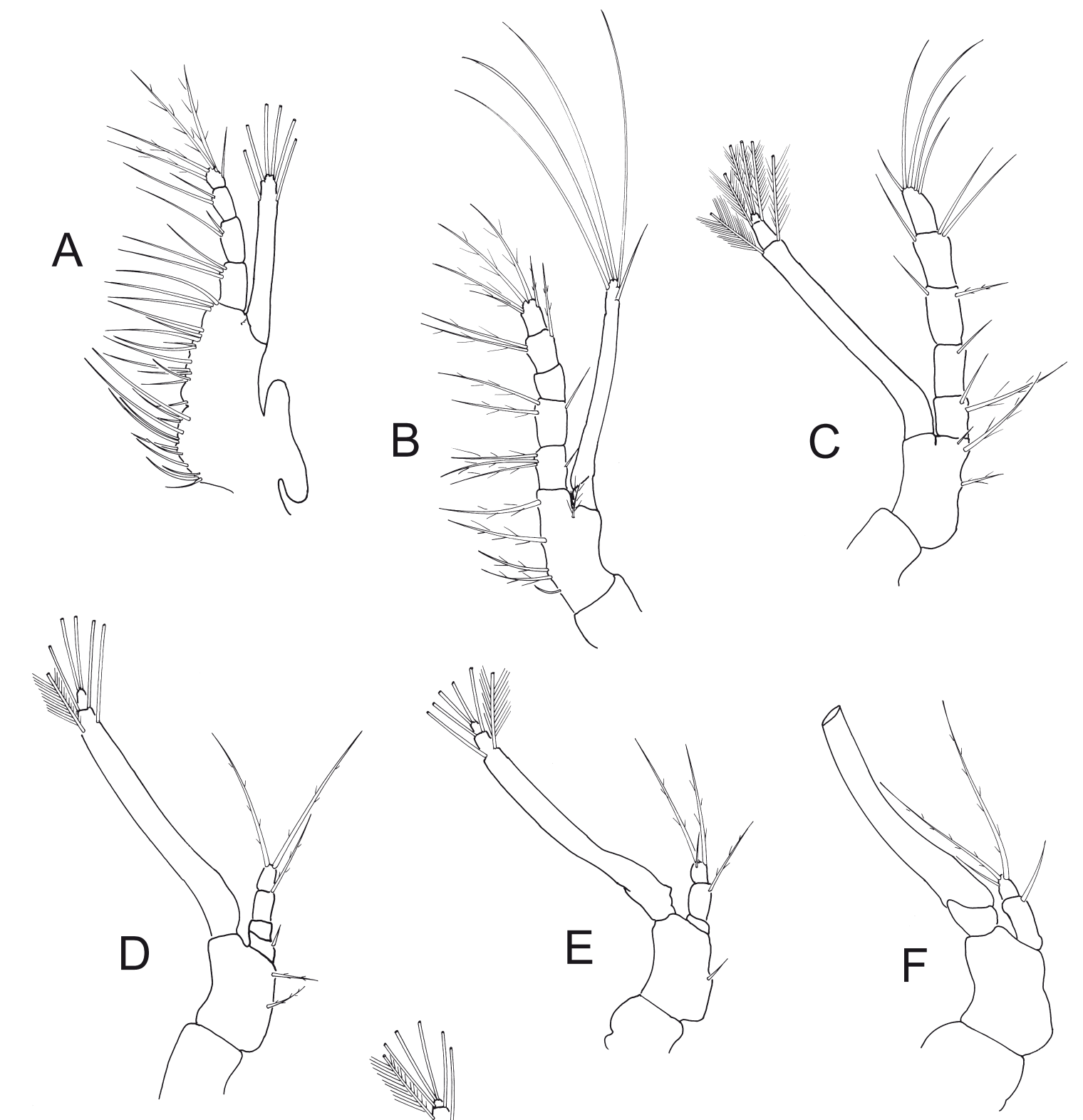

F-H

A-E
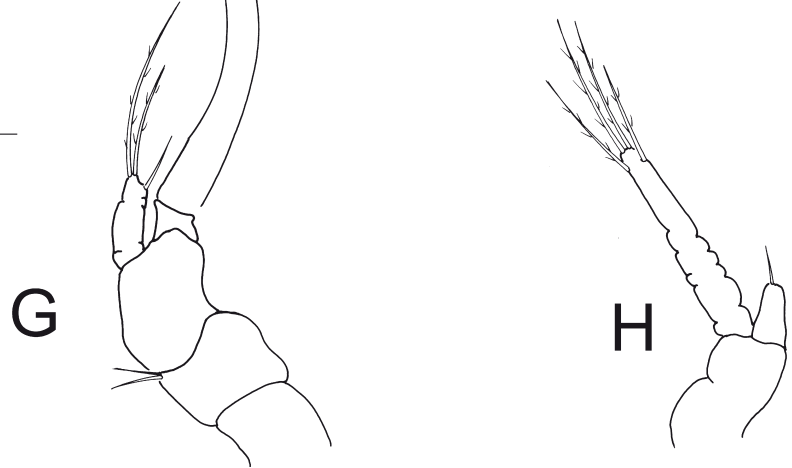

FIG. 3. - Appendages of mysis II of red shrimp Aristeus antennatus (Risso, 1816). A, first maxilliped; B, second maxilliped; C, third maxilliped; D, first pereiopod; E, second pereiopod; F, third pereiopod; G, fourth pereiopod; H, fifth pereiopod. Scale bars: $1 \mathrm{~mm}$. 
2B); supraorbital spines and prominent pterigostomial spines present; eyes reaching posterior end of antennular peduncle.

Antennule (Fig. 2D): peduncle 3-segmented, proximal segment with 8 plumose setae distributed along inner margin, 3 small plumose setae on stylocerite, 1 simple spine positioned at mid-length of segment and 6 plumose setae distally; second segment with 2 plumose setae along inner margin, 1 sparsely plumose seta on outer margin and 2 plumose and 1 simple setae distally on outer margin; distal segment with 2 plumose setae along inner margin and 4 long plumose setae, 4 short plumose setae and 1 simple small seta distally. Inner flagellum unsegmented, with 1 small simple seta on distal margin. Outer flagellum unsegmented, with 2 aesthetascs placed sub-terminally and 4 aesthetascs and 1 simple seta distally.

Antenna (Fig. 2E): protopod without setae; scaphocerite with 13 plumose setae sparsely distributed along inner margin and 5 plumose setae on distal outer margin; flagellum composed of 11 segments, with 1 small simple seta on distal margin of the fifth segment and 1 small plumose seta on distal margin of the ninth segment and 3 more on the posterior end of the distal segment.

Mandible (Fig. 2F): armature of incisor and molar processes as illustrated, incisive part with numerous teeth; palp unsegmented, with 1 long plumose distal seta.

Maxillule (Fig. 2G): coxal endite with 8 serrulate, papposerrate and simple seta; basial endite with 10 strong cuspidate and 4 sparsely plumose setae; endopod 2-segmented with 2 sparsely plumose setae on the proximal segment and $2,2+2$ sparsely plumose setae on distal segment.

Maxilla (Fig. 2H): coxal endite bilobed with $6+12$ long plumose setae; basial endite bilobed with $7+4$ plumose setae; endopod 4-segmented bearing $2+2+2+2$ long plumose setae and 1 small simple seta on distal segment plus an additional endite at its base with 2 plumose setae; scaphognathite with 22 marginal plumose setae.

First maxilliped (Fig. 3A): protopod slightly bilobed, proximal coxal portion with 12 papposerrate setae; distal basial portion with 14 papposerrate setae along margin and 1 small papposerrate seta on distal end between exopod and endopod; endopod 4-segmented with 3,2, 2, 4+1 papposerrate setae; exopod unsegmented with 6 long plumose setae on distal margin; epipod bilobed.

Second maxilliped (Fig. 3B): coxa without setae; basis with $1+2+1+1$ papposerrate setae; endopod 5 -segmented with $3+1,2+1,0,2+1,2+2$ papposerrate setae and 1 additional simple seta on distal segment; exopod unsegmented, with 5 long plumose setae on distal end.

Third maxilliped (Fig. 3C): coxa without setae; basis with 2 papposerrate and 1 simple seta; endopod 5-segmented, with $2,1,1+1,2+1,4$ papposerrate and 1 simple setae; exopod 3-segmented, with 2, 2, 2 plumose setae distally.
First pereiopod (Fig. 3D): coxa without setae; basis with 2 papposerrate setae; endopod 4 -segmented, first segment with 1 simple seta and 1,2 papposerrate setae on last two segments; exopod 2-segmented, with $2+2$, 2 long plumose setae.

Second pereiopod (Fig. 3E): coxal endite without setae; basis with 1 simple seta; endopod 3-segmented, with $0,1,1+2$ papposerrate setae; exopod 2-segmented, with $2+2,2$ long plumose setae distally.

Third pereiopod (Fig. 3F): coxa and basis without setae; endopod 2-segmented, with 1 simple seta on first segment and $1+2$ papposerrate setae on terminal segment; exopod damaged.

Fourth pereiopod (Fig. 3G): coxal endite with 2 small simple setae on posterior margin; basis unarmed; endopod unsegmented, with $1+2$ papposerrate setae; exopod unsegmented, with $2+2+2$ long plumose setae distally.

Fifth pereiopod (Fig. $3 \mathrm{H}$ ): coxa and basis partially segmented and without setae; endopod unsegmented, with 1 simple seta terminally; exopod unsegmented, with $2+2$ long plumose setae.

Pleon (Fig. 2A, C): first to fifth pleomere unarmed; sixth pleomere with one pair of lateral spines and 1 small ventral spine.

Pleopods (Fig. 2C): developed as small uniramous buds.

Uropods (Fig. 2I): protopod with a strong median carina ending as a very strong curved spine; endopod with 19 plumose setae along margin; exopod longer than endopod with 22 and 23 plumose setae along inner and posterior margins and without outer spine.

Telson (Fig. 2I): long, slender and biramous posteriorly, each branch with 4 spines on the inner side, two small ones on the outer side and 1 strong spine terminally; a pair of small lateral spines on the posterior margin of telson.

\section{Morphological description of zoea I of Scyllarides latus (Fig. 4)}

Size: $2.0 \mathrm{~mm}$ TL and $1.1 \mathrm{~mm}$ CL.

Pereion (Fig. 4A): extremely flattened dorso-ventrally; cephalic shield pear shaped, about as long as wide. Eyes (Fig. 4B) stalked, longer than wide, slightly longer than antennules, peduncle cone shaped.

Antennule (Fig. 4C): unsegmented and uniramous, with 3 aesthetascs, 2 simple setae and 1 small spine at distal margin, and small denticle located at two thirds of its length on inner margin.

Antenna (Fig. 4C): unsegmented and biramous; endopod 2-segmented, with 4 terminal setae; exopod unsegmented, with 2 terminals spine-like setae.

Labrum (Fig. $4 \mathrm{D}_{1}$ ): superior portion simple, inferior portion bifid.

Mandibles: symmetrical (Fig. $4 \mathrm{D}_{3}$ ).

Maxillule (Fig. $4 \mathrm{D}_{4}$ ): biramous and unsegmented; coxal endite with 1 strong cuspidate and 2 shorter setae; basial endite with 2 strong terminal cuspidate and 2 simple spine setae sub-terminally. 


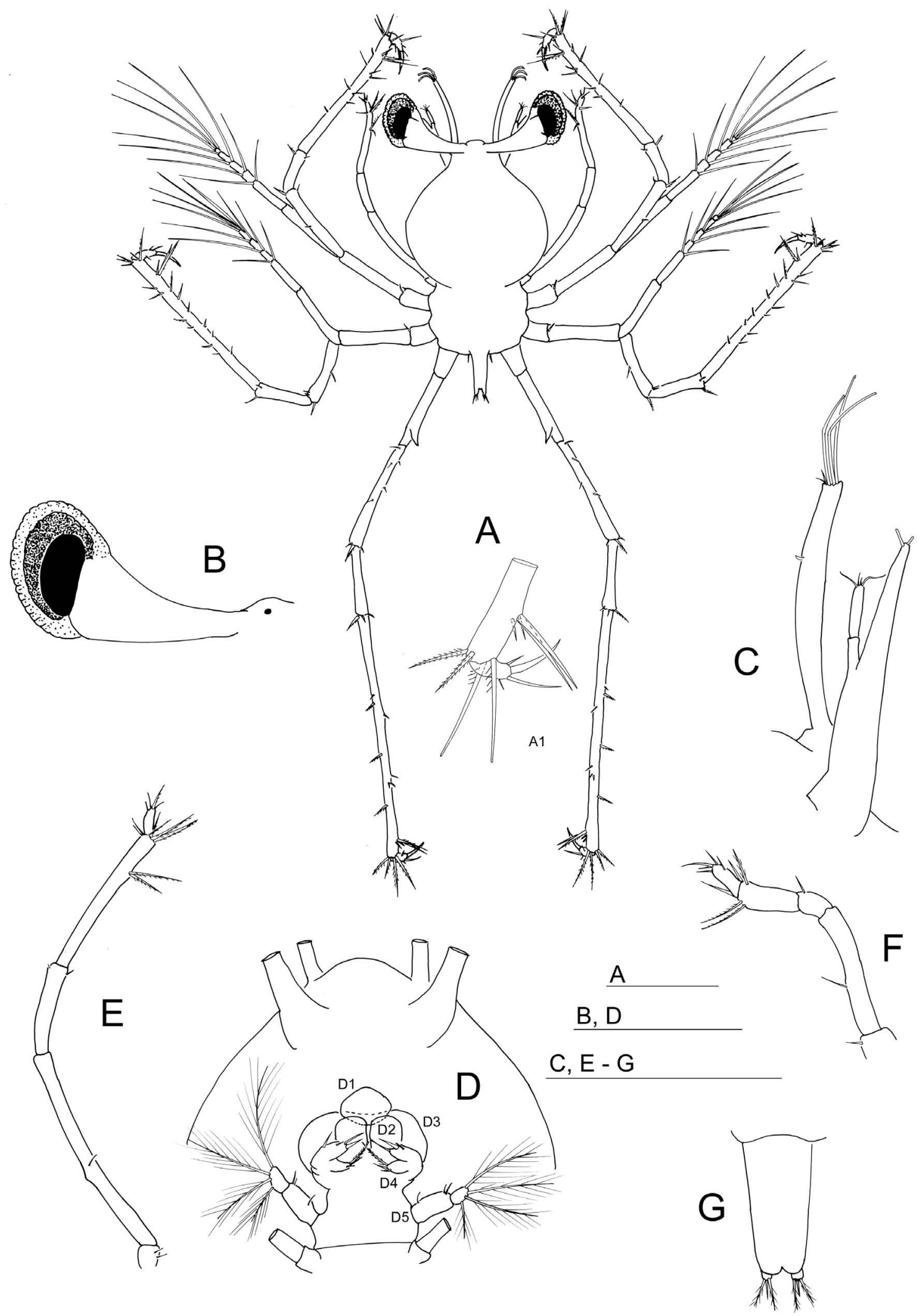

FIG. 4. - Zoea I (phyllosoma) of Mediterranean slipper lobster Scyllarides latus (Latreille, 1803). A, dorsal view; $\mathrm{A}_{1}$, detail of the dactyl of the third pereiopod; $\mathrm{B}$, right eye; $\mathrm{C}$, antennule and antenna; $\mathrm{D}$, masticatory apparatus; $\mathrm{D}_{1}$, dorsal view of labrum; $\mathrm{D}_{2}$, paragnaths; $\mathrm{D}_{3}$, mandible; $\mathrm{D}_{4}$, maxillule; $\mathrm{D}_{5}$, maxilla; E, third maxilliped; F, second maxilliped; $\mathrm{G}$, pleon and telson. Scale bar: $1 \mathrm{~mm}$. 
Maxilla (Fig. 4D 5 ): Uniramous, 2-segmented, longer proximal segment with $1+2$ simple setae, shorter distal segmented with 4 plumose setae.

First maxilliped: absent.

Second maxilliped (Fig. 4F): uniramous, 5-segmented, with 1 (simple), 1 (simple), 1 (simple), 5 (2 serrate and 3 papposerrate), 4 (simple) +1 (stout and simple) setae.

Third maxilliped (Fig. 4A, 4E): uniramous, 5-segmented; first segment with 2 short simple setae; second segment with 1 simple seta located mid-length; third segment with 2 simple seta at distal margin; fourth segment has 2 stout serrated spines sub-terminally and 2 on distal margin and 4 short papposerrate setae; fifth segment with 3 papposerrate and 1 simple seta.

First pereiopod (Fig. 4A): biramous; coxa with 1 distinct coxal spine, basis unarmed; endopod 4-segmented, first segment with 1 small spine at mid-length and $1+1$ spines terminally, second segment with $1+1$ serrate setae on distal margin, third segment, the longest, with inner margin serrated and several plumodenticulate and serrate setae placed as shown; distal segment with 4 simple setae, 1 small spine and 1 stout simple setae terminally; exopod 6-segmented with 0,2 , 2, 2, 2 and 2 long plumose setae, respectively.

Second pereiopod (Fig. 4A): biramous; with 1 coxal spine and basis unarmed; endopod 4-segmented and serrated on inner margin, first segment with 1 spine at mid-length and $2+1$ serrate spines terminally, second segment with $2+1$ serrate setae on distal margin, third segment, the longest, several plumodenticulate and serrate setae placed as shown; distal segment with 4 simple setae and 1 stout seta terminally; exopod 6-segmented with $0,2,2,2,2$ and 2 long plumose setae.

Third pereiopod (Fig. 4A, 4A 1 ): about 1.3 times the length of first and second pereiopods; coxa and basis unarmed; endopod 4-segmented, first segment with 1 simple seta proximally, 3 small setae along the margin and $2+1$ serrate spines terminally, second segment with $2+1$ serrate setae on distal margin, third segment, the longest, with several plumodenticulate and serrate setae placed as shown; short distal segment with 3 simple setae and 1 stout seta terminally; exopod present as a small bud.

Fourth and fifth pereiopods: absent.

Pleon (Fig. 4A, 4G): unsegmented, longer than wide, slightly rounded posteriorly.

Pleopods: absent.

Uropods: absent.

Telson (Fig. 4G): bilobed, not completely separated from the pleon from the ventral side, with 3 setae on each side, 2 setose and 1 simple.

\section{DISCUSSION}

The nekto-benthic behaviour and deep water dwelling of the adults of some decapod crustaceans often makes obtaining and rearing such species in laboratory conditions very difficult. This fact is one of the reasons for our scant knowledge on the morphology and duration of larval phases of these species. This is especially problematic in Penaeoidea, which release their fertilized eggs freely into the water column, hatching as nauplius larvae. In other decapods, the eggs remain attached to the female pleopods for incubation and the larvae hatch in a more advanced zoeal developmental stage. Therefore, any information about larval morphologies of these species obtained from plankton sampling in the wild is valuable, even though it is based on few specimens and hence the variability in the development of some characters among individuals cannot be fully recorded. The way in which we identified the larvae of the considered species and the importance of our findings for improving knowledge on their larval development and ecology are discussed below.

\section{Second mysis of Aristeus antennatus}

Laboratory rearing of Penaeideans is not easy and for a number of them the description of several larval stages is still lacking. Therefore, descriptions from plankton samples are still required, since they are necessary to carry out quantitative studies of larval abundance and distribution, and to obtain a broad knowledge of the larval ecology of these species for sustainable management under an ecosystem approach. In this regard, Heldt (1955) described some larval stages of A. antennatus from plankton samples taken in the Balearic Sea in the summer of 1954 by means of horizontal hauls at the surface. Using some larvae captured alive, this author undertook some rearing experiments, allowing her to follow and document the progression from second protozoea to the first mysis stage, and thus establish a developmental sequence that she attributed to this species.

Heldt (1955) also described for the first time the larval stages of Aristaeomorpha foliacea. Since both descriptions were made from wild plankton samples, and therefore the larvae were of unknown parentage, she deduced their identity as follows: 1) the known Penaeoidea species for the western Mediterranean at the time were Gennadas elegans, Aristaeomorpha foliacea, Aristeus antennatus, Solenocera membranacea, Funchalia woodwardi, P. longirostris, Melicertus kerathurus and Sicyonia carinata; 2) P. longirostris, $M$. kerathurus and $S$. carinata could be eliminated as candidates as she obtained the juvenile form from larvae cultured in laboratory; 3 ) she established the identity of larvae of $S$. membranacea and G. elegans by laboratory studies using live protozoea I and protozoea II, respectively; 4) for F. woodwardi the decapodid and several mysis stages were already described from plankton samples; 5) by exclusion she attributed the two Penaeoidea larval series obtained to the remaining two species with unknown larvae, Aristaeomorpha foliacea, Aristeus antennatus; and 6) further evidence was that the larval series were found within the main fishery areas and during the reproductive period known for the latter two species. 
TABLE 2. - List of differences between the present study and Santucci $(1925,1928)$ for first larval stage of Scyllarides latus.

\begin{tabular}{|c|c|c|c|c|c|c|}
\hline & & & Number and type o & of setae on: & & Ornamentation \\
\hline & Antennule & Maxillule & Maxilla & Maxillipeds & Telson & Pereiopods \\
\hline Santucci $(1925,1928)$ & 4 setae & No description & $\begin{array}{l}\text { Eccentric and } \\
\text { elongated, with } \\
4 \text { distal setae }\end{array}$ & No description & 2 long spines & No description \\
\hline Present work & $\begin{array}{l}3 \text { aesthetascs, } \\
2 \text { simple setae } \\
\text { and } 1 \text { small spine } \\
\text { at distal margin. }\end{array}$ & $\begin{array}{l}\text { coxal endite: } 1 \\
\text { cuspidate and } 2 \\
\text { short setae; } \\
\text { basial endite: } 2 \\
\text { cuspidate terminal } \\
\text { and } 2 \text { simple } \\
\text { sub-terminally } \\
\text { spines. }\end{array}$ & $\begin{array}{l}\text { 2-segmented: } \\
\text { proximal segment } \\
\text { with } 1+2 \text { simple } \\
\text { setae; distal } \\
\text { segmented with } \\
4 \text { plumose setae. }\end{array}$ & $\begin{array}{l}\text { 1st maxilliped: } \\
\text { absent. 2nd } \\
\text { maxilliped } \\
\text { uniramous, } \\
\text { 5-segmented with } \\
1,1,1,5,4+1 \\
\text { setae. } \\
\text { 3rd maxilliped: } \\
\text { uniramous, } \\
\text { 5-segmented with } \\
2,1,1,2+2+4 \text {, } \\
3+1 \text { setae. }\end{array}$ & $\begin{array}{l}\text { with } 3 \text { setae on } \\
\text { each side, } 2 \\
\text { plumose and } 1 \\
\text { simple. }\end{array}$ & $\begin{array}{l}\text { First pereiopod: biramous, } \\
\text { coxa with } 1 \text { spine, basis } \\
\text { unarmed, endopod } \\
\text { 4-segmented: } 1+1+1,1+1,0 \text {, } \\
\text { 4+1+1 setae, exopod } \\
\text { 6-segmented with } 0,2,2,2,2,2 \\
\text { long setae. } \\
\text { Second pereiopod: biramous, } \\
\text { coxa with } 1 \text { spine, basis } \\
\text { unarmed, endopod } \\
\text { 4-segmented: } 1+2+1,2+1,0 \text {, } \\
\text { 4+1 setae, exopod 6-segmented } \\
\text { with } 0,2,2,2,2,2 \text { setae. } \\
\text { Third pereiopod: about } 1.3 \text { the } \\
\text { length of } 1 \text { st and } 2 \text { nd pereiopod, } \\
\text { biramous, coxa and basis } \\
\text { unarmed, endopod } 4-\text { seg- } \\
\text { mented: } 1+3+2+1,2+1,0,3+1 \\
\text { setae, exopod as a small bud. }\end{array}$ \\
\hline
\end{tabular}

Finally, the assignment of these two larval series to each of the two remaining species was based on size evidence and pigmentation. Noting size differences in larvae, Heldt attributed the series with bigger larvae to A. foliacea, since the adults of this species are bigger than those of A. antennatus. However, aware that small larvae do not always correspond to small adults, e.g. $S$. membranacea has big larvae and small adults, she also considered pigmentation. Adults of A. foliacea are readily distinguishable from any other species by their strong red colour and she was able to observe that specimens of one of the larval series, the one with bigger larvae, possessed the strong red pigment that was distinctive from the metanauplius stage onward. Therefore, the larval series with smaller larvae and light red pigmentation was attributed to A. antennatus.

We based our identification of the second mysis stage on the morphological features distinguishing the first mysis of $A$. antennatus and $A$. foliacea: according to Heldt (1955), the first mysis stage of A. antennatus can be distinguished from the same stage of A. foliacea by the presence of long pterigostomian spines in the former species and the presence of dorsal spines and postrostral carina on the carapace in the latter species. In addition, the antennal endopod is longer than the exopod in A. foliacea. Finally, the telson in A. antennatus is composed of two cylindrical rami, as in typical Penaeoidea larvae, but in A. foliacea the median cleft on the telson is not so clearly distinguished (see plates XVI and VIII Fig. a, respectively, in Heldt 1955).

The second mysis stage described in the present study possesses strong pterigostomian spines and the rostrum does not have dorsal spines or a carina, and we can still recognize the two cylindrical rami on the posterior end of the telson. This therefore places it in the larval sequence of $A$. antennatus described by Heldt
(1955). The main reasons for assigning the larva described here to the second mysis stage are: (i) the specimen possesses pleopod buds, absent from the previous stage; (ii) the $4^{\text {th }}$ pereiopod, which was rudimentary in mysis I, is now functional; (iii) the $5^{\text {th }}$ pereiopod has an endopod and exopod, the latter with setae, which in the previous stage is just a simple bud; and (iv) the endopod of the antenna is two times longer than the scaphocerite, which in the previous stage was about the same length.

\section{First zoea of Scyllarides latus}

The species-specific identity of scyllarid larvae has been confirmed only for a few species in the world (Webber and Booth 2001; Holthuis 2002), which makes systematic comparative studies almost impractical. Santucci (1925) described the first stage of $S$. latus from Mediterranean samples taken in the wild, confirming identification after comparison with individuals obtained from rearing experiments (Santucci, 1928). This author stated that both groups of specimens corresponded to the first developmental stage of S. latus. Santucci (1928) also compared these $S$. latus larvae with older larvae described previously by Stephensen (1923) as S. latus. He concluded that the larvae described by Stephensen (1923) were in fact the fourth zoeal stage of Scyllarus arctus.

Considering that the larva described here possesses all the characteristics described by Santucci (1928), we assigned it to the first larval stage of $S$. latus. The present description adds more detailed morphological information, not mentioned previously by Santucci $(1925,1928)$. The new information refers to the number and type of setae on the antennules, maxillule, maxilla, maxillipeds and telson, and we also give more 
details on the ornamentation of the three pereiopods (see Table 2 for details). We also give more details on the morphology of the pleon and telson. This should not only improve the identification of this species but also be useful in comparisons with other species of the genus and family.

\section{Occurrence and abundance of larval species}

Although occurrences of the target species were rare among all the collected material, our findings of A. antennatus larvae are in agreement with previous reports in the Balearic Islands (Heldt 1955; Carbonell et al. 2010) and with the known spawning season of this species for the area, from May to September, with a maximum in June-August (Carbonell 2005, Guijarro et al. 2008). The occurrence of A. antennatus larvae in near-surface layers of the water column is also in accordance with previous records and with the reproductive model proposed for this species, in which newly hatched larvae perform an ontogenetic migration through the water column to euphotic waters (Carbonell et al. 2010). The finding of the second mysis stage at surface layers agrees with the hypothesis of Sardà et al. (2004), in which all larval stages develop in these more productive waters until the decapodid stage, which moves to deeper waters to reach the benthic habitat of adults. Of the three captured larvae, two were caught off northwestern Mallorca, an area where the highest concentrations of mature females were detected in summer (Guijarro et al. 2008). However, the distribution of A. antennatus larvae in the study area depends not only on the location of spawners but also on circulation of water masses and topographic features around the Balearic Archipelago (Carbonell et al. 2010).

The two larvae of $P$. longirostris reported in the present study were captured in surface waters over the shelf break, corresponding to the upper limit of distribution of the adults. This larval presence in shallower areas than those where the highest abundance of adults has been found, i.e. at circa $350 \mathrm{~m}$ depth (Guijarro et al. 2009), supports the possibility of displacement of adults during the spawning period to lower depths (Dos Santos 1998). These larvae were found during two different periods (July and December), which coincide with the spawning period of the species in the area. Although maturing females have been found all year round, two peaks have been detected in June-August and November (Guijarro et al. 2009).

Although the duration of larval stages of species of Scyllarides cannot be accurately estimated, complete larval development should require several months, perhaps nine to eleven (Robertson 1969, Martins 1985). In the Gulf of Mexico, phyllosoma larvae of Scyllarides nodifer have been shown to have the ability to remain in the area for 8-9 months, with a circulation system that supports local recruitment (Lyons 1970). Taking into account the early stage of the larva of $S$. latus found in surface waters in July, one month after the maximum peak of the spawning of this species in the Balearic Islands (Reñones et al. 2010), and the current velocities around the archipelago (Pinot et al. 2002), it is highly likely that this larva originated from an adult population dwelling in the same area.

Stevcic (1967) reported three broods for Maja squinado per year in the Adriatic Sea, between March and August. Similarly, laboratory experiments have shown that this species spawns between March and July (Durán et al. 2011b) and that, at a water temperature of $18^{\circ} \mathrm{C}$, it takes $4-5$ days post-hatch to reach the zoea II stage, 9-10 days to reach the megalopa stage and 16-17 days after hatching to reach the first crab instar (Durán et al. 2011a). The last zoeal stage reported in our study was captured in surface waters in July 2010. The presence of larvae in the area, in addition to some sporadic catches of adult specimens reported since 2009, could be an indication of the success of the restocking program of this species, carried out at Mallorca Island, where juveniles hatched and reared in captivity have been released in the sea since 2008 .

In summary, our study is an important contribution to knowledge on the distribution and abundance of rare larval stages of benthic invertebrates and provides new information about larvae of species of interest for fishing and conservation. We describe in detail, for the first time, the second mysis stage of Aristeus antennatus and the first larval stage of Scyllarides latus, poorly known since its first report dates back almost one century. We also report the occurrence of the larval stages of A. antennatus, Parapenaeus longirostris. S. latus and Maja squinado in the plankton of the western Mediterranean, which represent the sixth, the third, the fourth and the second worldwide finding of these species, respectively. In the case of $P$. longirostris and $S$. latus it represents the first captures from the field of larval stages for these species in the Mediterranean.

Although the scarcity of data indicates the need for further studies to obtain a global understanding of the larval development of these decapod crustaceans, these new descriptions will facilitate the identification of larval stages of species of interest for a wider community of researchers and hence the generation of new information about the larval ecology and the recruitment, which will be useful for improving the management of these species.

\section{ACKNOWLEDGEMENTS}

The research was carried out within the framework of the IDEADOS (CTM2008-04489-C03-01) project funded by the Plan Nacional I+D+i. The authors are very grateful to all the colleagues and crew members who participated in the IDEADOS surveys on board the R/V Sarmiento de Gamboa. We are particularly grateful to Olga Reñones for providing suggestions that helped to improve the manuscript, and to Ferran Palero and Pere Abelló for phyllosome taxonomic con- 
firmation. A.P. Torres acknowledges pre-doctoral FPI Fellowship support from the regional government of the Balearic Islands, Conselleria d'Educacció, Cultura i Universitats, selected as part of an operational programme co-financed by the European Social Fund.

\section{REFERENCES}

Abelló P., Guerao G. 1999. Temporal variability in the vertical and mesoscale spatial distribution of crab megalopae (Crustacea: Decapoda) in the Northwestern Mediterranean. Estuar. Coast. Shelf Sci. 49: 129-139.

Bannister C. 1993. Summary of the session 6 (Restocking) of the IV International Lobster Workshop. The Lobster Newsletter 6(2): 6-7.

Botsford L.W., Moloney C.L., Hastings A., Largier J.L., Powell T.M., Higgins K.,Quinn J.F. 1994. The influence of spatially and temporally varying oceanographic conditions on meroplanktonic metapopulations. Deep-Sea Res. Part II 41: 107-145.

Bourdillon-Casanova L. 1960. Le méroplancton du Golfe de Marseille: Les larves de crustacés décapodes. Rec. Trav. Stat. Mar Endoume 30: 1-286.

Carbonell A. 2005. Evaluación de la gamba rosada, Aristeus antennatus (Riso 1816), en el Mar Balear. Ph.D. Thesis, Universitat de les Illes Balears, $212 \mathrm{pp}$.

Carbonell A., Dos Santos A., Alemany F., Vélez-Belchi P. 2010. Larvae of the red shrimp Aristeus antennatus (Decapoda: Dendrobranchiata: Aristeidae) in the Balearic Sea: new occurrences fifty years later. Mar. Biodiv. Rec. 3: e103.

Cartes J.E., Papiol V., Guijarro B. 2008. The feeding and diet of the deep-sea shrimp Aristeus antennatus off the Balearic Islands (Western Mediterranean): Influence of environmental factors and relationship with the biological cycle. Prog. Oceanogr. 79: $37-54$

Clark P.F., Calazans D.K., Pohle G.W. 1998. Accuracy and standardization of brachyuran larval descriptions. Invertebr. Reprod. Dev. 33: 127-144

Dos Santos A. 1998. On the occurrence of larvae of Parapenaeus longirostris (Crustacea: Decapoda: Penaeoidea) off the Portuguese coast. J. Nat. Hist. 32: 1519-1523.

Dos Santos A., Lindley J.A. 2001 Crustacea Decapoda: Larvae II. Dendrobranchiata (Aristeidae, Benthesicymidae, Penaeidae, Solenoceridae, Sicyonidae, Sergestidae, and Luciferidae). ICES Identification Leaflets for Plankton. Fiches d'identification du plancton 186.

Dos Santos A., Gonzalez-Gordillo J.I. 2004. Illustrated keys for the identification of the Pleocyemata (Crustacea: Decapoda) zoeal stages, from the coastal region of south-western Europe. J. Mar. Biol. Ass. U. K. 84: 205-227.

Durán J., Pastor E., Grau A., Valencia J.M. 2011a. First results of embryonic development, spawning and larval rearing of the Mediterranean spider crab Maja squinado (Herbst) under laboratory conditions, a candidate species for a restocking program. Aquacult. Res. 43: 177-1786.

Durán J., Pastor E., Llabrés M. 2011b. Efecto del fotoperiodo sobre la ovoposición y puesta de la centolla mediterránea, Maja squinado. Proceedings of the "XIII Congreso Nacional Acuicultura", Barcelona, (Spain) 21-24, p. 141

Fehlauer K.H., Freire A.S. 2002. Occurrence of decapods larvae, specially Xiphopenaeus kroyer (Penaeidea) in the shallow shelf of Paraná. Nauplius 10: 37-45.

Fusté X. 1982. Ciclo anual de las larvas de Crustáceos Decápodos de la costa de Barcelona. Inv. Pesq. 46: 287-303.

Fusté X. 1987. Distribución de larvas de Crustáceos Decápodos de la costa de Cataluña. Inv. Pesq. 51(Supl. 1): 277-284

Garm A. 2004. Mechanical functions of setae from the mouth apparatus of seven species of decapod crustaceans. J. Morphol. 260: $85-100$

González-Gordillo J.I., Rodríguez A. 2003. Comparative seasonal and spatial distribution of decapod larvae assemblages in three coastal zones off the south-western Iberian Peninsula. Acta Oecol. 24: 219-233.

Goñi R., Latrouite D. 2005. Biology, ecology and fisheries of $\mathrm{Pa}$ linurus spp. species of European waters: Palinurus elephas
(Fabricius, 1787) and Palinurus mauritanicus (Gruvel, 1911). Cah. Biol. Mar. 46: 127-142

Guerao G., Abelló P. 1997. Larval development of the spider crab Macropodia longipes (Brachyura: Majidae: Inachinae). J. Crustac. Biol. 17: 459-471.

Guerao G., Abelló P. 1999. The first zoeal stage of Parthenope macrochelos (Herbst, 1790) hatched in the laboratory (Crustacea : Brachyura : Parthenopidae). Sci. Mar. 63: 9-14.

Guerao G., Abelló P., Dos Santos A. 2006. Morphological variability of the megalopa of Liocarcinus depurator (Brachyura: Portunidae) in Mediterranean and Atlantic populations. J. Nat. Hist. 40: 1851-1866

Guerao G., Pastor E., Martin J., Andres M., Estevez A., Grau A., Duran J., Rotllant G. 2008. The larval development of Maja squinado and M. brachydactyla (Decapoda, Brachyura, Majidae) described from plankton collected and laboratory-reared material. J. Nat. Hist. 42: 2257-2276

Guijarro B., Massuti E., Moranta J., Diaz P. 2008. Population dynamics of the red shrimp Aristeus antennatus in the Balearic Islands (western Mediterranean): Short spatio-temporal differences and influence of environmental factors. J. Mar. Syst. 71: 385-402

Guijarro, B., Massutí E., Moranta J., Cartes J.E. 2009. Short spatiotemporal variations in the population dynamics and biology of the deep-water rose shrimp Parapenaeus longirostris (Decapoda: Crustacea) in the western Mediterranean. Sci. Mar. 73: 183-197.

Harvey A.W., Martin J.W., Wetzer R. 2002. Phylum Arthropods: Crustacea. In: Young C.M., Sewell M.A., Rice M.E. (eds), Atlas of marine invertebrate larvae. Academic Press, San Diego, pp. 337-370.

Heldt J.H. 1938. La reproduction chez les crustacés Décapode de la Famille de Pénéides. Ann. Inst. Oceanogr. 18: 31-206

Heldt J.H. 1954. Stades larvaires d'Aristeomorpha foliacea (Risso) et Aristeus antennatus (Risso). Décapodes Penéides. Compt. Rend. Acad. Sci. 239: 1080-1082.

Heldt J.H. 1955. Contribution à l'étude de la biologie des crevettes pénéides Aristaeomorpha foliacea (Risso) et Aristeus antennatus (Risso) (Formes larvaires). BSSNT VIII 1-2, 1-29.

Holthuis L.B. 2002. The Indo-Pacific scyllarine lobsters (Crustacea, Decapoda, Scyllaridae). Zoosystema 24: 499-683.

Ingle R.W. 1993. Hermit crabs of the Northeastern Atlantic Ocean and the Mediterranean Sea. Chapman and Hall, London, $502 \mathrm{pp}$.

Landeira J.M. 2010. Larvas planctónicas de crustáceos decápodos en las Islas Canarias. PhD thesis, Tech. Univ. de La Laguna. Departamento de Biología Animal. Unidad de Investigación de Ciencias Marinas.

López-Jurado J.L., Marcos M., Monserrat S. 2008. Hydrographic conditions affecting two fishing grounds of Mallorca island (Western Mediterranean): during the IDEA Project (20032004). J. Mar. Syst. 71: 303-315

Lyons W.G. 1970. Scyllarid lobsters (Crustacea, Decapoda). Mem. Hourglass Cruises 1(4): 1-74.

Maigret J. 1978. Contribution a l'étude des langoustes de la cote occidentale d'Afrique. 5. Les larves phyllosomes de Scyllarides et de Palinuridae recueillies au large des cotes du Sahara. Bull. Inst. Fondam. Afr. Noire Ser. A. Sci. Nat. 40: 36-80

Martins H.R. 1985. Some observations on the naupliosoma and phyllosoma larvae of the Mediterranean locust lobster, Scyllarides latus (Latreille 1803), from the Azores. ICES CMK 52: 13.

Moranta J., Quetglas A., Massutí E., Guijarro B., Ordines F., Valls M. 2008. Research trends on demersal fisheries oceanography in the Mediterranean. In: Mertens L.P. (ed.), Biological Oceanography Research Trends. Nova Science Publishers, Inc., Hauppauge, New York, pp. 9-65.

Olivar M.P., Sabates A., Abelló P., Garcia M. 1998. Transitory hydrographic structures and distribution of fish larvae and neustonic crustaceans in the north-western Mediterranean. Oceanol. Acta 21: 95-104.

Olivar M.P., Bernal A., Moli B., Pena M., Balbin R., Castellon A., Miquel J., Massuti E. 2012. Vertical distribution, diversity and assemblages of mesopelagic fishes in the western Mediterranean. Deep-Sea Res. I 62: 53-69.

Pinot J.M., López-Jurado J.L., Riera M. 2002. The canals experiment (1996-1998). Interannual, seasonal, and mesoscale variability of the circulation in the Balearic channels. Prog. Oceanogr. 55(3-4): 335-370 
Reñones O., Coll J., Díaz D., Morey G., Martino S., Navarro O., Stobart B., Deudero S., Grau A. M. 2010. Estudio de la biología y ecología de Scyllarides latus en el Parque Nacional Marítimo del Archipiélago de Cabrera. Implicaciones para la gestión de la especie en las Islas Baleares. Informe proyecto LATUS 20062009. Instituto Español de Oceanografía, $61 \mathrm{pp}$

Robertson P.B. 1969. The early larval development of the scyllarid lobster Scyllarides aequinoctialis (Lund) in the laboratory, with a revision of the larval characters of the genus. Deep Sea Res. 16: $557-586$

Santucci R. 1925. Contributo allo studio dello sviluppo postembrionale degli Scyllaridea del Mediterraneo II: Scyllarus arctus. III: Scyllarides latus. Mem. R. Com. Talassogr. Ital. 71: 1-16.

Santucci R. 1928. Il primo stadio post-embrionale di Scyllarides latus Latreille. Mem. R. Com. Talassogr. Ital. 144: 1-7.

Sardà F. 1998. Nephrops norvegicus (L.): Comparative biology and fishery in the Mediterranean Sea. Introduction, conclusions and recommendations. Sci. Mar. 62(Suppl. 1): 5-15.

Sardà F., D’Onghia G., Politou C.Y., Maiorano P., Kapiris K. 2004. Deep-sea distribution, biological and ecological aspects of Aristeus antennatus (Risso, 1816) in the western and central Mediterranean Sea. Sci. Mar. 68: 117-127.
Seridji A. 1971. Contribution a l'étude des larves crustacés décapodes en baie d'Alger. Pelagos 3: 1-107.

Spanier E., Lavalli K.L. 1998. Natural history of Scyllarides latus (Crustacea: Decapoda): a review of the contemporary biological knowledge of the Mediterranean slipper lobster. J. Nat. Hist. 32: $1769-1786$

Stephensen K. 1923. Decapoda-Macrura excluding Sergestidae. Rep. Danish Oceanogr. Exped. 1908-10, 2, Biol. D 3: 1-85.

Stevcic Z. 1967. A short outline of the biology of the spinous spider crab. Bull. Sci. Conseil Acad. RSF Yougoslavie, sec. A 12: 313-314.

Webber W.R., Booth J.D. 2001. Larval stages, developmental ecology, and distribution of Scyllarus sp. Z (probably Scyllarus aoteanus Powell, 1949) (Decapoda: Scyllaridae). N.Z. J. Mar. Freshwat. Res. 35: 1025-1056.

Yearsley J.M., Sigwart J.D. 2011. Larval transport modeling of deep-sea invertebrates can aid the search for undiscovered populations. PLOS ONE 6(8): e23063.

Scient. ed.: C. Zeng.

Received September 19, 2012. Accepted January 18, 2013.

Published online February 26, 2013. 